Volume 1 No (1) 2019

\title{
SANKSI HUKUM YANG DAPAT DIBERIKAN OLEH HAKIM KEPADA ORANG MEMBANTU MELAKUKAN TINDAK PIDANA PENCURIAN DI PENGADILAN NEGERI PADANGSIDIMPUAN
}

\author{
Marwan Busyro ${ }^{1}$ \\ ${ }^{1}$ Fakultas Hukum Universitas Muhammadiyah Tapanuli Selatan, Sumatera Utara
}

\begin{abstract}
ABSTRAK
Adapun materi yang disajikan dalam penelitian ini adalah sanksi hukum yang dapat diberikan oleh Hakim kepada orang yang membantu melakukan tindak pidana pencurian di Pengadilan Negeri Padangsidimpuan sebab dalam hal tindak pidana pencurian yang mana pelakunya lebih dari satu orang, yang diantaranya adalah untuk membantu supaya terlaksana pencurian itu, maka dalam hal ini penulis perlu melakukan penelitian hukuman apasajakah yang dapat diberikan oleh Hakim terhadap orang yang membantu melakukan tersebut dengan demikian penulis mengambil lokasi penelitian pada Pengadilan Negeri Padangsidimpua, dan Advokat serta Kejaksaaan Negeri Padangsidimpuan. Sedangkan tujuan penelitian adalah karena perbuatan membantu melakukan tindak pidana pencurian dapat meresahkan masyarakat, maka perlu diketahui bagaimanakah sanksi hukumnya yang diberikan oleh Hakim terhadap pelaku tindak pidana tersebut dalam persidangan di Pengadilan Negeri Padangsidimpuan dan karena perbuatan membantu melakukan tindak pidana masih terdapat di dalam masyarakat, maka perlu diketahui apakah yang menjadi faktor penyebabnya terjadinya tindak pidana pencurian tersebut di wilayah Hukum Pengadilan Negeri Padangsidimpuan. Selanjutnya metode penelitian yang penulis gunakan dalam penulisan penelitian ini adalah penelitian deskriptif dan penelitian normatif yang maksudnya adalah penelitian yang dilakukan dengan hasil wawancara penulis dengan responden dan juga melakukan penelitian terhadap data-data maupun berkas-berkas yang berkaitan dengan penelitian ini seperti Kasus Nomor; 473/Pid.B/2008/PN.Psp dengan cara penelitian Penelitian Lapangan (Library Research) dan Penelitian Kepustakaan (Field Research). Sedangkan teknik atau alat yang penulis gunakan dalam mengumpulkan data baik dilapangan maupun dalam melakukan wawancara dengan responden yang ditemui penulis serta data yang diambil dari dokumen yang berkaitan dengan permasalahan yang dirumuskan dalam penelitian ini yaitu Interview (Wawancara) dan Studi Dokumentasi yang selanjutnya akan dianalisan dengan cara Induksi dan Deduksi. Selanjutnya sebagai kesimpulannya adalah bahwa penjatuhan saksi hukum yang dapat diberikan Hakim terhadap orang yang melakukan tindak pidana pencurian masih relatip ringan jika dibandingkan dengan maksud Pasal 57 Kitab Undang-undang Hukum Pidana yang menentukan bahwa hukuman kepada orang yang membantu melakukan selama-lamanya hukuman pokok bagi kejahatan dikurangi sepertiga dalam hal membantu melakukan kejahatan tersebut dan bahwa yang merupakan faktor dominan penyebab seseorang mau melakukan peran membantu melakukan tindak pidana pencurian di wilayah Hukum Pengadilan Negeri Padangsidimpuan adalah disebabkan adanya faktor karena kemiskinan yang mengharap imbalan dan adanya rasa dendam
\end{abstract}

Kata Kunci ; Tindak Pidana Pencurian, Sangsi Hukum 


\section{PENDAHULUAN}

Hukum sebagai gejala sosial adalah merupakan suatu kenyataan dari kehidupan masyarakat atau dalam arti kata yang lain bahwa segala bentuk hubungan diantara manusia di dalam masyarakat baik yang sesuai dengan norma-norma atau kaedah kehidupan manusia maupun yang dilarang sudah digambarkan di dalam hukum. Oleh karena itu maka dapat dikatakan bahwa apa yang sudah ditetapkan di dalam hukum adalah sudah merupakan suatu patokan dalam bentuk pemerintahan maupun larangan untuk suatu kehidupan manusia di dalam masyarakat yang bertujuan agar dapat diciptakan suatu kehidupan yang adil, tertib dan sejahtera sehingga diharapkan akan tercipta kehidupan yang aman dan bahagia.

Keadaan seperti ini secara khusus dapat kita lihat di dalam penggambaran tata hukum Nasional dimana Pemerintah Negara Republik Indonesia sejak dari kemerdekaannya sudah berusaha untuk membangum keberadaan hukum Nasional dengan untuk dapat menciptakan kehidupan kenegaraan yang bersih dan berwibawa, maka dengan demikian diharapkan tujuan Negara Republik Indonesia sebagaimana yang tertuang di dalam Undang-undang Dasar 1945 untuk menciptakan masyarakat yang adil dan makmur baik secara materil maupun secara sprituil akan dapat dicapai

Pentingnya hukum sebagai alat pembaharuan negara memang dapat disadari dengan mengingat sejarah kehidupan bangsa Indonesia yang mengalami masa penjajahan selam 350 tahun dari bangsa Belanda sehingga banyak hukum produk Belanda yang diberlakukan untuk orang-orang Indonesia pada waktu itu dan hingga sekarang masih ada hukum peninggalan Bangsa Belanda itu yang masih berlaku secara jelas sudah harus mengalami perubahan untuk menyesuaikannya dengan kondisi kehidupoan masyarakat Indonesia yang berdasarkan Pancasila dan Undang-undang Dasar 1945. Oleh karena itulah maka pemerintah di dalam upayanya untuk pembaharuan hukum di Indonesia sangat menaruh perhatian yang sungguhsungguh dalam membangun Hukum Nasional agar antara pembangunban fisik dan pembangunan secara mental dapat seimbang. Dan untuk itulah maka pada masa Pembangunan Jangka Panjang (PJP) I (pertama) atau masa pembangunan 25 tahun I (pertama), maka berbagai produk hukum telah diciptakan untuk memungkinkan bangsa Indonesia berhasil melaksanakan pembangunan pada masa Pembangunan (PJP) II (kedua) yang kini memasuki era tinggal landas. Upaya-upaya pembinaan hukum Nasional yang sudah dilaksanakan oleh pemerintah tersebut hendaknya mendapat perhatian yang sungguhsungguh dari semua lapisan masyarakat baik dari kalangan aparat pemerintah sebagai 
penegak hukum maupun dari kalangan masyarakat biasa untuk menghindarkan terjadinya pelanggaran hak maupun kepentingan dari segenap individu.

Suatu kenyataan yang dapat dilihat di dalam masyarakat masih banyak terjadi pelanggaranbpelanggaran hukum khususnya yang dimaksudkan penulis adalah terjadinya berbagai tindak pidana seperti pencurian, pembunuhan, perampokan, penipuan maupun penganiayaan. Terjadinya tindak pidana tersebut dapat dilaksanakan oleh setiap orang perorangan maupun oleh dua orang atau lebih yang bekerja sama untuk melakukan suatu tindak pidana, sehingga dikenal beberapa istilah di dalam hukum pidana yang disebut dengan orang yang melakukan (Pleger), orang yang menyuruh melakukan (Doen Plegen) orang yang turut melakukan (Medelleger) dan orang yang dengan pemberian, salah memakai kekuasaan, memakai kekerasan dan sebagainya dengan sengaja membujuk melakukan perbuatan itu yang disebut dengan (Uitlokker).

Kemudian ada satu istilah lainnya di dalam hukum pidana yang disebut dengan membantu melakukan (Medeplichtig) yaitu orang yang dengan sengaja memberikan bantuan, kesempatan, daya upaya atau keterangan untuk terjadinya suatu kejahatan atau untuk melakukan suatu tindak pidana. Kejahatan-kejahatan me,bantu melakukan itu sangat sering terjadi dalam timbulnya suatu tindak pidana, hal ini di dasarkan kepada suatu pendapat penulis bahwa tidak mungkin misalnya seseorang pencuri atau perampok yang berasal dari tempat lain dapat mengetahui situasi atau keadaan suatu tempat (lorong) dimana tindak pidana itu dilaksanakan atau dengan mengetahui jalan masuk dan keluar yang strategis tanpa bantuan atau keterangan dari orang lain. Dengan adanya bantuan keterangan, kesempatan maupun daya upaya, maka organisasi kejahatan itu akan dapat mengetahui obyek sasaran ataupun mangsa, tempat atau lokasi dan situasi yang paling tepat untuk melakukan niat jahatnya kepada seseorang atau rumah tangga.

Dengan demikian sebagaimana yang terdapat di dalam Kitab Undang-undang Hukum Pidana (KUHP) dengan secara tegas mengancam perbuatan membantu melakukan suatu tindak pidana kejahatan ini, hal ini diatur secara tegas di dalam Pasal 56 dan Pasal 57 Kitab Undangundang Hukum Pidana (KUHP). Sesuai dengan penjelasan pasal tersebut maka kepada Hakim diberi kewenangan untuk menghukum orang-orang yang membantu melakukan, apakah hukumannya dikurangi 1/3 dari hukuman pokok, atau hukumannya dikurangi 1/3 dari hukuman yang dijatuhkan kepada si pelaku atau kemungkinan lain dengan melihat duduk perkaranya. Dari ketiga kemungkinan jenis penghukuman terhadap orang yang membantu melakukan tersebut diatas untuk masing-masing wilayah hukum Pengadila ada kemungkinannya tidak sama sehingga oleh penulis merasa tertarik dalam melakukan 
penelitian terhadap hukuman yang ditetapkan Hakim terhadap orang yang membantu melakukan tindak pidana ini. Berdasarkan penjelasan tersebut di atas, penulis merasa tertarik untuk mengangkat masalah ini sebagai judul penelitianyaitu : "Sanksi Hukum Yang Dapat Diberikan Oleh Hakim Kepada Orang Membantu Melakukan Tindak Pidana Pencurian Di Pengadilan Negeri Padangsidimpuan”

\section{METODE PENELITIAN}

\section{Lokasi Penelitian}

Sesuai dengan hal tersebut di atas penulis akan melakukan suatu penelitian atau suatu karya ilmiah seharusnya peneliti harus menentukan dimana lokasi penelitian agar supaya memudahkan bagi penelitian dalam melakukan ataupun dalam mengumpulkan data yang ada kaitannya dengan permasalahan yang diangkat dalam penelitian ini. Sesuai dengan penjelasan penulis tersebut di atas maka lokasi penelitian adalah di pada Pengadilan Negeri Padangsidimpuan sebab lokasi tersebut adalah merupakan salah satu tempat penulis untuk melakukan wawancara dan sekaligus dalam hal untuk mengumpulkan data yang berkaitan dengan masalah yang diteliti dalam rumusan masalah yang ada dalam penelitian ini.

\section{Pendekatan Penelitian}

Selanjutnya penulis menguraikan terlebih dahulu apa pengertian dari pada penelitian sebelum menguraikan bagaimanakah metode penelitian yang akan dilakukan dalam penulisan penelitian ini, sebagaimana menurut pendapat Gempur Sentosa mengenai tentang pengertian penelitian yaitu : "Penelitian adalah salah satu proses pemecahan masalah dengan menggunakan prosedur yang sistematis, logis dan empiris sehingga akan ditemukan suatu kebenaran hasil penelitian ilmiah adalah kebenaran atau pengetahuan ilmiah yang selanjutnya disebut dengan penelitian atau riset (Research) (Gempur Sentosa, 2005).

Sesuai dengan penjelasan tersebut di atas sudah jelas bahwasanya di dalam melakukan penelitian ataupun untuk menyusun suatu karya ilmiah khususnya bagi penulis sendiri yang akan menyusun suatu penelitian untuk mengakhiri perkuliahan dalam hal mencapai gelar kesarjanaan maka penulis akan melakukan penelitian yang dilakukan dengan penelitian riset (Research) yang harus diiukut sertakan karena penelitian ini adalah merupakan suatu langkah untuk menjawab terhadap permasalahan yang dirumuskan dalam penelitian ini. Sejalan dengan penjelasan penulis tersebut di atas dimana telah menguraikan pengertian dari pada 
pengertian penelitian maka sampailah pada metode penelitian sebagaimana yang akan penulis kemukakan di bawah ini yaitu :

1. Penelitian Pustaka (Library Research) yaitu : penulis mempelajari literature (buku-buku) karangan para sarjana yang ada kaitannya dengan penulisan penelitian ini, seterusnya penulis mengolah data-data yang dapat diperlukan untuk melengkapi penelitian ini

2. Penelitian Lapangan (Field Research) yaitu : penulis langsung melakukan penelitian terhadap objek-objek tertentu dan meminta keterangan dari pihak yang berwenang

\section{Jenis Penelitian Yang Digunakan}

Selanjutnya penulis akan menjelaskan tentang jenis penelitian yang digunakan oleh penulis dalam penelitian ini yaitu penelitian Normatif yaitu suatu penelitian yang berdasarkan kepada Undang-undang dan peraturan perundang-undang serta berupa Putusan Pengadilan Negeri Padangsidimpuan yang telah berkekuatan hukum tetap yang ada menyangkut tentang permasalahan yang akan diteliti oleh penulis.

\section{Populasi Dan Sampel}

Pengertian dari pada populasi sebagaimana yang dikemukakan oleh Suharsini Arikunto (1987) yaitu : "Setiap penelitian senantiasa memiliki objek penelitian dimana keseluruhan objek penelitian ini disebut sebagai populasi” . pengertian dari pada populasi sebagaimana tersebut di atas maka penulis akan memberikan populasi sebagai berikut adalah para Hakim Pengadilan Negeri Padangsidimpuan serta Putusan Pengadilan Negeri Padangsidimpuan Selanjutnya penulis akan memberikan sampel yang akan dilakukan oleh penulis akan tetapi sebagaimana yang dikemukakan oleh Sumadi Suryabrata sebagai berikut : "Diantara berbagai teknik penentuan sampel yang dianggap paling baik adalah hanya terletak pada teori yang mendasarinya tetapi juga pada bukti empiris”

Sesuai dengan hal tersebut di atas maka sebagai sampel dalam penelitian ini yang diambil adalah seorang Hakim Pengadilan Negeri Padangsidimpuan, Jaksa Penuntut Umum dan Advokat serta Putusan Pengadilan Negeri Padangsidimpuan yang ada hubungannya dengan penelitian ini

\section{Sumber Data}

Sementara sumber data yang penulis lakukan sesuai dengan permasalahan yang telah dirumuskan adalah :

1. Data Primer yaitu data yang dihasilkan dari pendapat para responden dengan melalui wawancara 
2. Data Skunder yaitu suatu data yang diambil dari literatur yang ada di perpustakaan dan Putusan Pengadilan Negeri Padangsidimpuan yang ada hubungannya dengan penelitian ini

\section{Teknik Pengumpulan Data}

Sedangkan teknik atau alat yang penulis gunakan dalam mengumpulkan data baik dilapangan maupun terhadap dokumen yang diperlukan penulis sendiri serta juga melakukan wawancara dengan responden yang ditemui penulis pada Pengadilan Negeri Padangsidimpuan yang ada kaitannya dengan permasalahan yang dirumuskan dalam penelitian ini adalah sebagai berikut :

1. Interview (Wawancara) yaitu dengan mengajukan pertanyaan-pertanyaan secara langsung kepada responden yang sebelumnya telah ditentukan terlebih dahulu

2. Studi Dokumen yaitu dengan mempelajari berkas-berkas yang telah diarsipkan di Pengadilan Negeri Padangsidimpuan

\section{Analisa Data}

Sebelum penulis sampai kepada masalah analisa data terlebih dahulu penulis adakan mengmukakan apa pengertian analisa tersebut sesuai dengan pendapat Sudarto yang mengatakan : "Mengolah data dengan menggunakan metode analisis yang dimaksudkan untuk mendapatkan pengetahuan ilmiah dengan mengadakan pemerincian terhadap objek yang diteliti dan menggabungkan beberapa pengertian diharapkan akan di dapatkan pengetahuan baru untuk pemahaman dan kejelasan arti yang dipahami” (Sudarto, 1997).

Berdasarkan pengertian dari pada analisa data tersebut di atas maka analisa data itu adalah suatu penganalisaan terhadap data-data yang terkumpul baik yang di dapat dari hasil wawancara maupun dari data dokumen yang terdapat dalam uraiuan di dalam penelitian maka penulis akan menggunakan cara penganlisaan data dengan cara :

1. Induksi yaitu mengelola data dari fakta yang bersifat khusus untuk mengambil suatu kesimpulan pada hal yang bersifat umum

2. Deduksi yaitu mengolah data dari fakta yang bersifat umum untuk mengambil suatu kesimpulan pada hal yang bersifat khusus 


\section{PEMBAHASAN}

\section{Sanksi Hukum Yang Diberikan Hakim Bagi Orang Membantu Melakukan Tindak Pidana Pencurian}

Sanksi hukuman yang dimaksud di dalam pembahasan ini adalah berapa lama hukuman yang ditetapkan Hakim kepada seseorang yang melakukan membantu melakukan tindak pidana kejahatan sebagai akibat dan ganjaran dari perbuatannya. Untuk mengetahui bagaimana penjatuhan hukum yang ditetapkan Hakim Pengadilan Negeri Padangsidimpuan terhadap orang yang melakukan membantu melakukan tindak pidana pencurian sebagaimana yang dimaksudkan di dalam perbuatan yang diatur pada Pasal 56 dan Pasal 57 Kitab Undangundang Hukum Pidana (KUHP), maka penulis sudah melaksanakan wawancara dengan Hakim Pengadilan Negeri Padangsidimpuan yang menjelaskan bahwa pedoman bagi Hakim dalam menjatuhkan hukuman terhadap orang yang membantu melakukan tindak pidana pencurian adalah di dasarkan kepada adanya pasal yang diancam dan tidak dibenarkan melebihi pidana yang dijatuhkan kepada pelaku utamanya karena pada prinsipnya hukuman yang dijatihkan kepada si pelaku adalah lebih berat dari pelaku utamanya.

Kemudian dijelaskan lagi bahwa dalam praktek penjatuhan pidana jarang sekali Hakim menjatuhkan hukuman pokok dan hukuman tambahan baik terhadap pelaku utamanya maupun untuk orang yang membantu melakukan tindak pidana pencurian kecuali terdapat faktor-faktor yang sangat mendukung untuk dijatuhkannya hukuman tambahan terhadap pelaku utama maupun orang yang membantu melakukan tindak pidana pencurian dapat dijatuhkan jenis pidana yang sama yaitu hukuman pokok maupun hukuman tambahan hanya saja pelaku utamanya hukumannya yang lebih berat dari yang membantu melakukan, namun hal yang harus diketahui bahwa hukuman tambahan tidak mungkin dijatuhkan tanpa adanya hukuman pokok seperti yang tertera dalam Pasal 10 Kitab Undang-undang Hukum Pidana (KUHP).

Sebagaina di dalam penjelasan lain juga dikemukakan oleh Hakim Pengadilan Negeri Padangsidimpuan tentang pertanggungjawaban pidana bagi orang yang membantu melakukan tindak pidana pencurian yaitu hal ini harus dilihat dari peranan seseorang yang turut melakukan tindak pidana jadi tergantung kepada elemen karena tidak semua harus dikurangi hukumannya 1/3. Berdasarkan penjelsan tersebut diatas dapat diketahui bahwa dalam menetapkan hukuman kepada seseorang yang membantu melakukan tindak pidana pencurian harus dapat dilihat sampai sejauhmana keterlibatannya di dalam perbuatan pidana itu 
misalnya apakah hanya dengan memberi kesempatan kepada si pelaku untuk melaksanakan kejahatannya.

Kalau hanya dengan memberikan keterangan mungkin hukumannya lebih diringankan sedikit dan apabila juga dengan memberi kesempatan kepada si pelaku sedangkan yang bersangkutan bertugas untuk mengwasi orang lain yang akan berbuat jahat terhadap benda yang dijaganya maka hukumannya akan lebih berat.Dengan demikian untuk menetapkan hukuman terhadap orang yang membantu melakukan tindak pidana pencurian ini Hakim harus meneliti sampai sejauhmana tindakan yang dilakukannya dalam perbuatan membantu melakukan tindak pidana pencurian itu dan oleh karena itu hukumannya tidak selamanya sebagaiamana yang dijelaskan di dalam penjelasan dari Pasal 57 Kitab Undang-undang Hukum Pidana (KUHP) karena bisa saja hukumannya bervariasi untuk orang-orang yang tersangkut paut dengan perbuatan membantu melakukan tindak pidana pencurian, misalnya ada yang dikurangi 1/3 dari hukuman pokok, ada yang ditambahi 1/3 dari hukuman yang dijatuhkan kepada si pelaku dan ada yang hanya dijatuhi hukum lebih 1/3 hukuman yang dijatuhkan kepada si pelaku dan ada juga yang hanya dijatuhi hukuman percobaan

\section{Tata Cara Dalam Menentukan Seseorang Membantu Melakukan Tindak Pidana Pencurian}

Apabila kita membicarakan tata cara untuk menentukan apakah seseorang terlibat dalam membantu melakukan suatu tindak pidana atau tidak maka yang berwenang mengkwalifikasikannya tiada lain adalah sebagai tugas Hakim dalam memutusnya dan Jaksa sebagai aparat Penuntut Umum untuk membuktikannya. Sebagaimana penjelasan tersebut di atas tugas seorang Hakim untuk memutuskan suatu perkara dengan penetapan seseorang terdakwa sebagai “membantu melakukan suatu tindak pidana pencurian” dan tugas seorang Jaksa Penuntut Umum adalah untuk menuntut dan membuktikan seseorang sebagai membantu melakukan tindak pidana pencurian bukanlah suatu pekerjaan yang ringan di dalam proses pradilan, karena untuk mengkualifikasikan sesuatu perbuatan itu sebagai membantu melakukan harus dengan mengkaji berita acara pemeriksaan polisi dan bukti yang sudah diterima kejaksaan dan kemudian oleh Jaksa sebagai Penuntut Umum membuat tuntutannya untuk disampaikan pada persidangan dan selanjutnya, oleh Hakim menganalisa tuntutan dan menyesuaikan dengan alat-alat bukti serta unsur perbuatan yang terdapat pada pasal-pasal yang dituntut di dalam Kitab Undang-undang Hukum Pidana.

Dengan demikian maka tatacara menentukan seseorang terlibat dalam sutu tindakan pidana membantu melakukan harus dengan suatu proses yang sudah ditetapkan secara Undang- 
undang yaitu mulai dari hasil penyidikan Polisi yang disampaikan kepada Jaksa dalam bentuk berita acara pemeriksaan dan atas dasar itu maka jaksa sebagai penuntut di persidangan yang seterusnya dipertimbangkan Hakim untuk menetapkan suatu putusan yang menentukan seseorang itu bersalah sebagai orang yang membantu melakukan. Apabila pendapat penulis tersebut dikaitkan dengan hasil penelitian yang dilaksanakan di Pengadilan Negeri Padangsidimpuan yaitu dengan bapak Hakim Pengadilan Negeri Padangsidimpuan beliau menjelaskan bahwa Hakim baru dapat menentukan bahwa pelaku tindak pidana pencurian tersebut berstatus sebagai pembantu/membantu melakukan apabila dengan fakta di persidangan pelaku dalam Surat Dakwaannya didakwa melanggar Pasal 56 KUHP.

Hal tersebut haruslah terbukti unsur-unsurnya sesuai dengan yang didakwakan oleh Jaksa Penuntut Umum. Dalam arti bahwa perbuatan yang dilakukan oleh terdakwa tersebut haruslah memenuhi unsur Pasal 56 Kitab Undang-undang Hukum Pidana. Disamping pendapat tersebut diatas, kami kemukakan pula pendapat dari seorang Hakim Pengadilan Negeri Padangsidimpuan sebagai hasil wawancara kami dengan yang bersangkutan yang mengatakan bahwa cara Hakim menentukan seseorang itu terlibat dalam perbuatan melakukan tindak pidana pencurian adalah dengan cara meneliti dari awal sampai akhir kemudian dengan menyesuaikan dengan keterangan saksi dan alat bukti yang diajukan Jaksa di Pengadilan.

Untuk kasus yang menyangkut dengan membantu melakukan tindak pidana, sesuai dengan penjelasan Hakim Pengadilan Negeri Padangsidimpuan Hakim Pengadilan Negeri Padangsidimpuan agak jarang ditemukan adanya membantu melakukan tindak pidana pencurian, hal ini di dasarkan kepada keadaan dimana pelaku tindak pidana pencurian yang sudah ditangkap dan telah diperiksa di Kepolisian akan berusaha untuk mengurangi beban tanggung jawabnya sebagai pelaku, sehingga untuk tercapainya maksud tersebut pelaku memberikan keterangan dalam Berita Acara Kepolisian bahwa perbuatan tersebut dilakukan secara bersama-sama. Dan akhirnya sampai di Kejaksaan akan didakwakan bahwa perbuatan dilakukan bersama-sama dan bukan perbuatan pembantuan.

Apabila keberadaan tindak pidana membantu melakukan yang terjadi di Wilayah Hukum Pengadilan Negeri Padangsidimpuan di kaitkan dengan pendapat dari Bapak Hakim Pengadilan Negeri Padangsidimpuan maka dia menjelaskan bahwa ia pernah memberikan bantuan hukum untuk orang yang membantu melakukan tindak pidana kejahatan dan bahkan juga sering diberikan bantuan yaitu dalam kasus-kasus pencurian, pembunuhan dan penganiayaan. Kemudian oleh Hakim Pengadilan Negeri Padangsidimpuan menjelaskan lagi bahwa tindak pidana membantu melakukan bisa saja terjadi terhadap semua jenis tindak 
pidana pencurian dan tidak terbatas pada salah satu jenis saja, karena pelaku tersebut dikatakan membantu melakukan tindak pidana apabila telah terpenuhi unsur-unsur dari Pasal 56 Kitab Undang-undang Hukum Pidana (KUHP), hanya saja di dalam praktek yang biasa terjadi adalah terhadap kejahatan yang menyangkut harta benda

\section{Faktor Penyebab Terjadinya Membantu Melakukan Tindak Pidana Pencurian}

Apabila kita membicarakan tentang faktor-faktor penyebab terjadinya membantu melakukan tindak pidana pencurian maka kita tidak terlepas dari membicarakan motif atau hal-hal yang mendorong bagi si pelaku untuk melakukan suatu perbuatan membantu melakukan tindak pidana pencurian. Oleh karena itu rangsangan dalam bentuk keinginan dari si pelaku untuk melakukan sesuatu perbuatan dengan harapan untuk memperoleh sesuatu imbalan atau karena tertekan akibat dari suatu ancaman ataupun bujuk rayuan ataupun karena rasa benci. Jadi dengan demikian perbuatan itu dilaksanakannya dengan suatu keinginan dengan perbuatan memberikan keterangan kepada orang lain yang bertindak sebagai pelaku tindak pidana pencurian. Suatu hal yang perlu untuk dipahami bahwa orang yang membantu melakukan tindak pidana pencurian sama sekali tidak bertindak sebagai pelaku kejahatan akan tetapi bertindak sebagai pelaksana dari kejahatan itu. Dengan keterangan yang dilaksanakan oleh orang yang membantu melakukan itu maka kejahatan yang dilaksanakan oleh orang lain tersebut akan terlaksana dengan petunjuk-petunjuk yang telah diberikan tersebut. Adapun faktor penyebab terjadinya tindak pidana membantu melakukan sebagaimana hasil wawancara penulis yang telah dilakukan terhadapa seorang Hakim Pengadilan Negeri Padangsidimpuan yang menjelaskan bahwa faktor seseorang terlibat dalam melakukan tindak pidana pencurian dan dalam arti membantu melakukan adalah antara lain :

a. Karena ingin mendapatkan keuntungan bagi dirinya atau orang lain

b. Karena adanya ancaman dari pelaku materil (pelaku utama)

c. Karena intimnya atau akrabnya dengan pelaku sehingga orang tersebut mau membantu melakukannya

Kemudian pendapat tentang motif seseorang mau melakukan membantu untuk melaksakan tindak pidana pencurian sebagaimana yang dijelaskan oleh seorang Advokat Bapak Tris Widodo. SH. MH yang mengatakan bahwa seseorang terlibat dalam membantu melakukan tindak pidana pencurian antara lain disebabkan oleh karena :

a. Karena kemiskinan yang mengharap imbalan

b. Karena dendam 
Berdasarkan penjelasan tersebut di atas dan dari hasil penjelasan kedua responden tersebut diatas yang menyangkut dengan motif terjadinya perbuatan membantu melakukan tindak pidana pencurian itu adalah saling berbeda akan tetapi menurut pengamatan penulis dapat dijadikan sebagai suatu hal yang saling melengkapi sehingga apabila disatukan kedua pendapat tersebut maka akan dapat diketahui bahwa faktor penyebab terjadinya membantu melakukan tindak pidana pencurian di wilayah Hukum Pengadilan Negeri Padangsidimpuan terdiri dari 5 motif yaitu :

a. Karena ingin mendapatkan keuntungan bagi dirinya atau orang lain

b. Karena adanya ancaman dari pelaku materil (pelaku utama)

c. Karena intimnya atau akrabnya dengan pelaku sehingga orang tersebut mau membantu melakukan

d. Karena kemiskinan yang yang mengharapkan imbalan

e. Karena dendam

Adapun motif terjadinya membantu melakukan tindak pidana pencurian tersebut diatas belum terlihat kepada kita adanya motif rasa benci kepada majikan yang disebabkan oleh karena kurang besar gaji atau karena persaingan dalam suatu usaha atau karena rasa iri kepada orang lain sehingga yang bersangkutan merasa tega untuk memberikan keterangan kepada orang lain untuk melakukan kejahatan di suatu tempat atau rumah. Apa yang merupakan hal yang belum terungkap dari penjelasan responden tentang motif atau faktor penyebab terjadinya perbuatan membantu melakukan tindak pidana pencurian ini menurut hemat penulis disebabkan karena pelaku yang tertangkap jarang yang mau memberitahu kepada petugas penyidik (polisi) bahwa masih ada orang lain yang tersangkut dengan peristiwa pidana tersebut, pada hal sebenarnya apabila diamati seuatu kejadian peristiwa pidana pada suatu tempat bahwa pelakunya adalah orang yang berasal dari luar daerah akan tetapi pelakunya mengetahui seluk beluk dari suatu rumah atau lokasi tertentu yang menurut pemikiran kita tidak mungkin diketahui oleh pelaku kejahatan itu sendiri

\section{KESIMPULAN DAN SARAN}

\section{Kesimpulan}

a. Bahwa penjatuhan saksi hukum yang dapat diberikan Hakim terhadap orang yang melakukan tindak pidana pencurian masih relatip ringan jika dibandingkan dengan maksud Pasal 57 Kitab Undang-undang Hukum Pidana yang menentukan bahwa 
hukuman kepada orang yang membantu melakukan selama-lamanya hukuman pokok bagi kejahatan dikurangi sepertiga dalam hal membantu melakukan kejahatan tersebut

b. Bahwa yang merupakan faktor dominan penyebab seseorang mau melakukan peran membantu melakukan tindak pidana pencurian di wilayah Hukum Pengadilan Negeri Padangsidimpuan adalah disebabkan adanya faktor karena kemiskinan yang mengharap imbalan dan adanya rasa dendam

\section{Saran}

a. Berhubung karena oknum pelaku membantu melakukan tindak pidana pencurian sangat sulit untuk mengungkapkannya karena bisanya pelaku kejahatan setelah tertangkap tidak mau memberitahukannya, maka diharapkan kepada Hakim dan Jaksa Penuntut Umum untuk dapat mengungkapkannya di persidangan

b. Untuk dapat memberi rasa aman kepada masyarakat dari ancaman dengan adanya tindak pidan pencurian maka kepada yang membantu melakukan kejahatan tersebut seharusnya perlu diberi hukuman yang lebih berat dan jangan hanya berdasarkan hukuman pokok akan tetapi ditambahi dengan sepertiga

\section{DAFTAR PUSTAKA}

Bambang Poernomo, 1982, Azas-azas Hukum Pidana, Ghalia, Indonesia

S. T. Kansil dan Christine Kansil, 1995, Hukum Pidana Untuk Perguruan Tinggi, Sinar Grafika, Jakarta

Gempur Sentosa, 2005, Metode Penelitian, Prestasi Pustaka Publisher, Jakarta

Roscoe Pound, 1982, Pengantar Filsafat Hukum, Bharata Karya Aksara, Jakarta

R. Sugandi, 1980, Kitab Undang-undang Hukum Pidana Dengan Penjelasannya, Usaha Nasional, Surabaya

Sumadi Suryabrata, 1983, Metodologi Penelitian, Rajawali, Jakarta

Suharsini Arikunto, 1987, Pengantar Prosedur Penelitian Suatu Pendekatan Praktik, Bina Aksara, Jakarta

Sudarto, 1997, Metodologi Filsafat, Raja Grafindo Persada, Jakarta

Winarno Surachmad, 1985, Pengantar Penelitian, Tarsito, Bandung

Wiryono Prijodikoro, 1981, Azas-azas Hukum Pidana Di Indonesia, Eresco, Jakarta 